\title{
Premium Compensation: The Ballooning Cost of Federal Government Employees
}

by

\author{
Alexandre Laurin and William B.P. Robson
}

- Fiscal pressures will eventually require the federal government to tackle the cost of its employees, whose compensation accounts for about 60 percent of the government's operating expenses. In particular, non-payroll expenses related to future benefits are mounting rapidly.

- The annual costs of deferred compensation, such as disability plans, future health and dental care, provisions for severance and sick-leave accumulation, and the value of accrued pension and other future benefits, have risen at doubledigit rates over the past decade. Worse, because the federal government does not fully recognize the impact of declining rates of return on the cost of funding future payments, it understates the cost of these promises.

- Ottawa should report the full value of its employees' deferred benefits, and ensure that the total value of its compensation is competitive with, but not vastly above, employees' outside alternatives. Freezing departmental operating budgets can help, but longer term, Ottawa should transition to target-benefit pensions for its employees, so that taxpayers do not continue to bear all the risks related to federal pension plans.

The federal government has been spending freely lately. While it has advertised rapid increases in spending as positive, various fiscal pressures - growing debt and interest payments, pressure to get tax rates down, and the greater need of provinces and territories for revenue - will eventually require Ottawa to rein it in. That task will require tackling the cost of federal employees, which has been rising rapidly. Total compensation per employee jumped by nearly 5 percent per year

We thank Malcolm Hamilton, the Office of the Parliamentary Budget Officer and several members of the C.D. Howe Institute's Fiscal and Tax Competitiveness Council for comments on an earlier draft. Responsibility for the conclusions and any remaining errors is ours. 


\section{Table 1: Federal Compensation Per Employee ${ }^{(1)}($ Average, $\$)$}

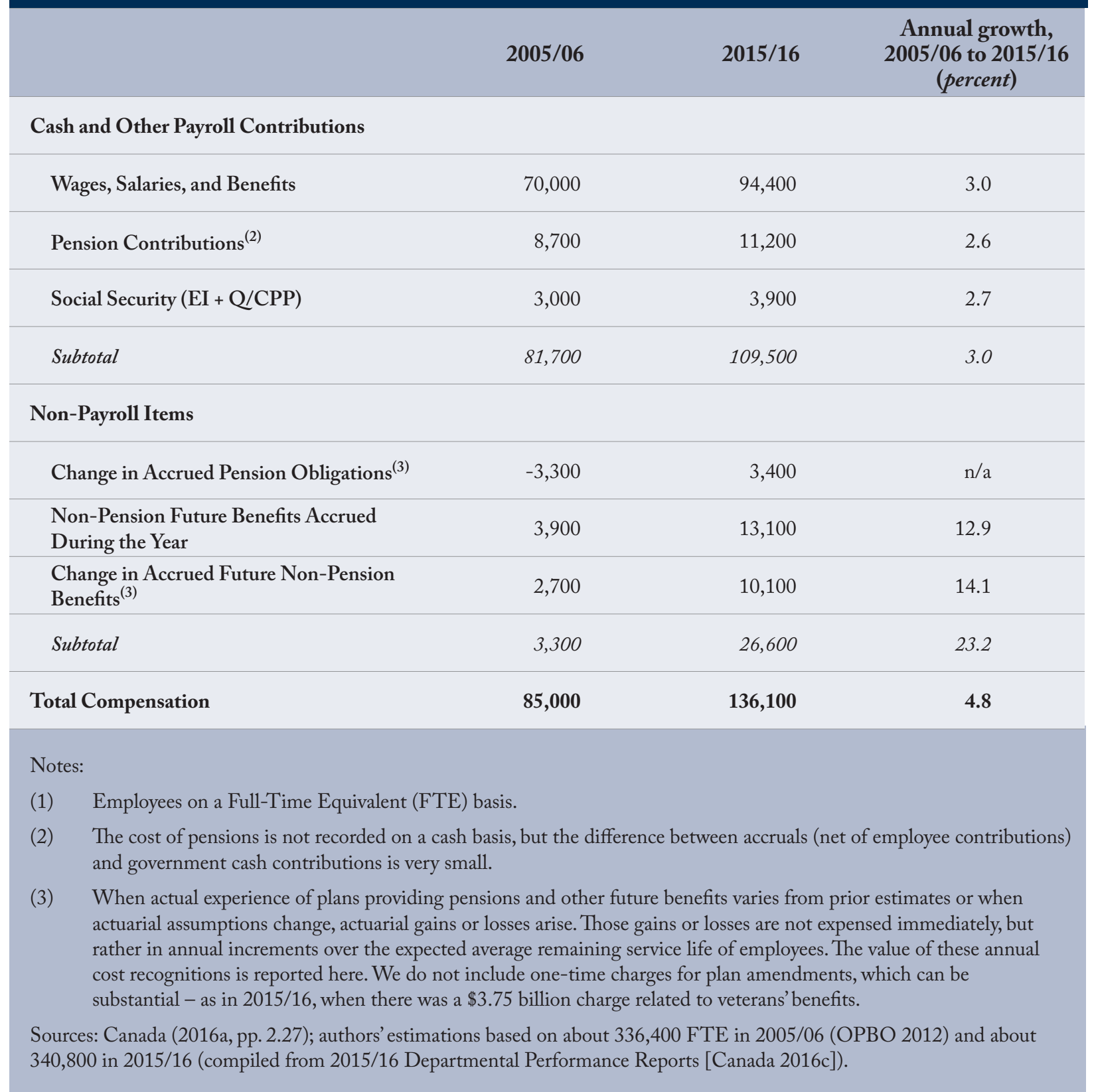

on average during the past decade (Table 1). Containing these increases will be tough but vital to getting federal spending onto a sustainable track.

While transfer payments and interest on debt together make up the bulk of federal spending, operating expenses account for about one-third of program expense. Of that, about 60 percent $-\$ 50.2$ billion - is compensation of employees. That price tag has two parts. One is what people usually think of as regular payroll expenses: wages and salaries, plus current payments for health and dental benefits, pension contributions and social-security contributions - Employment Insurance (EI) and the Canada and Quebec Pension Plans (C/QPP). 
The other is less front-of-mind but has been rising dramatically over time: non-payroll expenses for the value of future benefits earned in a given year and accumulating as unfunded liabilities.

On a dollars-per-employee basis, cash and other payroll contributions stood at $\$ 81,700$ in fiscal year $2005 / 06$. By $2015 / 16$, they had risen to $\$ 109,500$ - an annual growth rate of 3.0 percent (Table 1). Over that same period, the annual cost of non-payroll items related to unfunded deferred compensation grew from $\$ 3,300$ per employee to $\$ 26,600$ per employee - a growth rate of 23.2 percent. Combining the two yields total compensation per full-time-equivalent job of $\$ 85,500$ in 2005/06, and $\$ 136,100$ in 2015/16 - a remarkable annual growth rate of 4.8 percent.

Ten years ago, non-payroll items (mostly accumulation of unfunded future benefits) represented 5 percent of total federal compensation. They now account for almost 20 percent.

\section{Cash and Other Payroll Contributions}

The contrast between the less remarkable growth rate of payroll costs and the rocketing increases in non-payroll costs reflects quite different circumstances affecting them. Ottawa has periodically acted to contain wages, salaries and other current benefits. The previous Conservative government partially froze departmental operating budgets in the early 2010s - part of an effort to get the federal budget back to balance after the 2008/09 slump. It also made changes to the pension plans of federal employees, which shrank the government's share of current pension-plan contributions and - by moving the normal retirement age for new hires closer to levels typical of the private sector - reduced pension contributions for new employees.

Notwithstanding those measures, the payroll measure has still run ahead of business-sector compensation ${ }^{1}$ and continues to be higher than necessary to attract and retain good workers. A Treasury Board Secretariat review of federal government compensation released in November 2006 compared wages and salaries of federal employees to private-sector benchmarks. It found that federal wages and salaries (excluding pensions and benefits) were higher than those in the private sector. ${ }^{2}$ The report concluded that once the higher cost of pensions and other non-cash benefits is added to salaries, compensation in the federal public sector was well ahead of private-sector benchmarks (Hamilton 2014). ${ }^{3}$

1 Business-sector compensation per job increased 2.7 percent annually on average from 2005 to 2015 (Statistics Canada's Table 383-0033).

2 In a subsequent article, the author of the Treasury Board review, James Lahey, estimated a total compensation premium for federal versus private-sector workers in the order of 15 to 20 percent (Lahey 2011).

3 Some observers note that the wage premium for federal employees is larger at lower and mid-level positions, and warn that narrowing the average premium would hurt Ottawa's ability to retain talent at higher levels. We note, however, that the federal government's pension plan - which, as we explore in the following paragraphs, is more generous than commonly understood - is a final-salary scheme that compensates senior positions very generously. The federal government appears to suffer negligible attrition among its senior employees until they reach the age of full pension eligibility, and suffers severe attrition after that. A more sensible compensation structure would neither incent people so overwhelmingly to stay until they become eligible for their pensions, nor incent them so strongly to leave after they become eligible. 


\section{Figure 1: Average Employee Compensation per Hour of Work, Selected Sectors,}

\section{7 to 2015 (\$)}

Dollars per hour

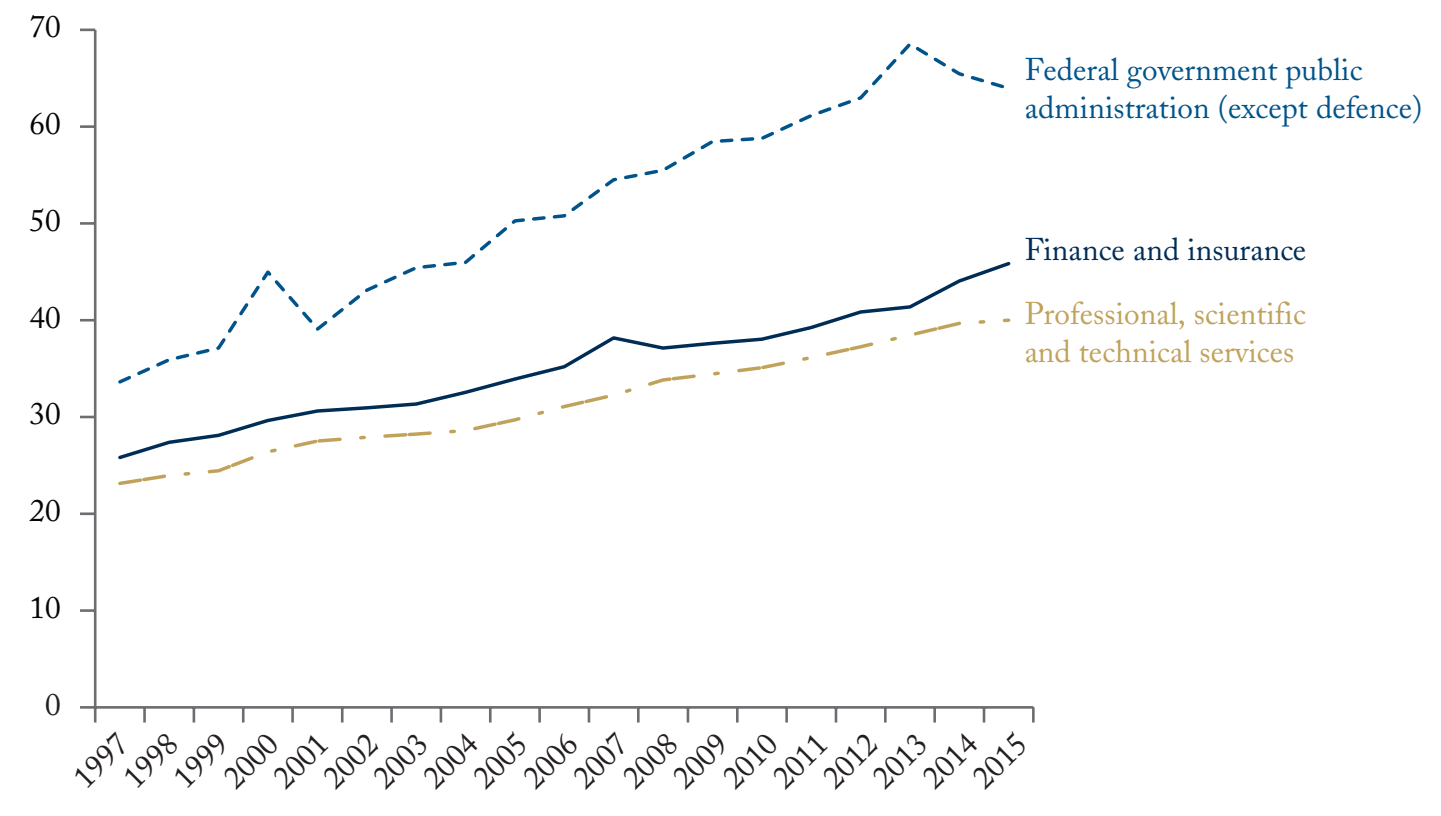

Source: Statistics Canada Table 383-0031.

What has happened since? One approach is to compare payroll compensation per hour worked in federal government service jobs (excluding defence) and private-sector service jobs in fields requiring relatively advanced qualifications. Despite declines in the per-hour measure in the last couple of years for which we have data, the gap between federal compensation and the most relevant comparators in the private-sector is still around one-third (Figure 1). Today, at $\$ 64$ per hour, average compensation in the federal government is still higher than in professional, scientific and technical service jobs ( $\$ 40$ per hour) or than in finance and insurance jobs ( $\$ 46$ per hour) - a margin about the same as that prevailing at the time of the Treasury Board review (Figure 1). On that basis, if federal compensation was ahead of its private-sector benchmarks in the early 2000s, it still is.

\section{Unfunded Future Benefits and Other Items}

What of non-payroll items? The cost of other, mostly deferred compensation has proved much harder to control. Benefits such as veterans' and police officers' disability plans, future health and dental care, provisions for severance and sick-leave accumulation, and the annual amounts reflecting the rising value of accrued pension and other future benefits are way up since 2005/06. 
A key driver of this increase is declining rates of return, which make a given future payment more expensive to fund. The cost of accruing non-pension future benefits increased from $\$ 3,900$ per employee in $2005 / 06$ to $\$ 13,100$ in 2015/16 as the expected federal long-term bond rate used to determine their value dropped from 5.1 to 2.4 percent. Adjustments to the estimated value of non-pension future benefits already earned increased from $\$ 2,700$ per employee in $2005 / 06$ to $\$ 10,100$ in $2015 / 16$. And whereas adjustments to the value of already accrued pension benefits subtracted $\$ 3,300$ from reported per-employee compensation in 2005/06, they added $\$ 3,400$ to it in $2015 / 16$. There, too, decreasing discount rates explain the rise in the reported cost of unfunded benefit liabilities in the past 10 years. ${ }^{4}$

Worse, the increases in pension liability that the federal government reports in its financial statements understate the value of these promises to their recipients and their cost to taxpayers. Ottawa's pension promises to its employees are part of the federal government's debt - indeed, they closely resemble federal real-return (inflation-indexed) bonds (RRBs). Someone not in a federal pension plan would need to fund a similar retirement - or, alternatively, to hedge against his or her liability for federal pensions as a taxpayer - by buying and holding a portfolio of the federal government's real-return bonds (Laurin and Robson 2016).

At the time of writing, the yield on RRBs is about 0.7 percent, reflecting the extraordinarily low yields lenders are willing to accept for relatively high-quality credit. Yet, unlike private-sector pension-plan sponsors, the federal government values its accrued pension obligations using arbitrary discount rates that average about 2.7 percent in real terms. ${ }^{5}$ As Hamilton (2014) points out, this means that taxpayers are guaranteeing plan participants long-term real rates of return around 3 percent - a guarantee of great value to participants and imposing great cost on taxpayers that does not appear in the federal government's statement of operations or its debt.

Matching benefits accruing in federal employee pension plans with the issuance of actual government debt - valued at the RRB rate or at the expected long-term bond rate used for valuing other future benefits - would increase both the pension contributions each year and the value of already accrued benefits. Valued at the RRB rate of at the end of the 2015/16 fiscal year ( 0.49 percent), the cost of pension contributions would have been about $\$ 30,500$ per employee higher - or more than triple - what is shown in Table 1 (row 3). ${ }^{6}$ The size

4 The nominal discount rate for accrued unfunded pension obligations dropped from 7.6 to 3.9 percent, and the nominal discount discount rate for other future benefit obligations dropped from 4.8 to 2.3 percent.

5 The federal government uses a discount rate based on historical bond rates (3.9 percent nominal) for benefits earned prior to 2000, and a rate based on expected rates of return on invested funds (5.8 percent nominal) for benefits earned after 2000. Inflation is assumed to remain at its 2 percent target.

6 Estimate based on the change to the current service cost of the Pension Plan for the Public Service of Canada, the largest federal employee pension plan. At the RRB rate, the sensitivity analysis in the latest actuarial report of the plan (Canada 2016b, p.82), suggests that the current service cost for all plans as recorded in the public accounts should be, not about 21 percent of pay, but about 54 percent of pay. Currently, government cash contributions to the plans and the annual expense recorded in the federal government's financial statements (published in the Public Accounts) are close in value. If the financial statements recorded annual pension expenses calculated using a more suitable, lower discount rate, the cash contributions would be lower than the recorded expense, and the difference would add to the unfunded liability in the pension plans, and therefore to the federal debt. 
of the liability for accrued pension benefit obligations would jump by $\$ 107$ billion, an amount that would be reflected, dollar for dollar, in the federal debt. ${ }^{7}$ Amortized over the average remaining service life of employees, ${ }^{8}$ the pension liability increase would add another $\$ 21,000$ per employee to total employee compensation costs (adjustments shown in Table 1, row 7). In total, per-employee compensation recorded in 2015/16 would be $\$ 51,500$ - or 38 percent - higher.

\section{Ensuring Competitive Employee Compensation}

The standard argument for providing generous pension benefits to federal employees is that public pressure constrains what Ottawa can pay in wages and salaries, and therefore it must use non-wage benefits to prevent its employees leaving for the private sector. This argument is open to two objections.

First, we know of no evidence that the federal government suffers significant attrition. The available data suggest that job turnover in the federal public service is much lower than in the private sector. ${ }^{9}$ There is an old adage to the effect that someone who never misses an airplane is spending too much time in airports. If federal compensation were more properly aligned to a competitive labour market, departures for the private sector would occur - some job turnover is a sign of a healthy labour market. The federal government could respond to particular pressures in particular areas with compensation adjustments in those areas, rather than maintaining across-the-board premiums.

Second, the right response to public pressure to keep employee compensation down is not to provide additional compensation that is effectively hidden from view; it is to make a public case for good compensation for valuable employees. The argument that Canada needs able people doing important federal government jobs is easy to make; the case that federal employees across the board should receive benefits that are far richer than most taxpayers enjoy, and that taxpayers cannot see, is not.

The recommendations flowing from this investigation are straightforward. First, the federal government should recognize the full value of its employees' deferred benefits using actual, not invented, discount rates, and include the annual changes in that value in its statement of operations.

Second, it should ensure that the total value of its compensation is competitive with the outside alternatives its employees face, understanding that the "right" level of compensation is one in which some departures do occur. In doing so, prolonged periods of departmental operating budget freezes, as occurred in the early 2010 s, is one of the most likely methods to succeed with the least possible disruptions of essential public services (Lahey 2011).

7 Estimated following the methods found in Robson and Laurin (2016) and prior annual C.D Howe Institute valuations of federal government pensions.

8 Assuming 15 years.

9 A report by the Public Service Commission of Canada estimated that, in 2007/08, just 1.4 percent of federal public servants holding permanent positions voluntarily departed the public service for reasons other than retirement (Canada 2008, p. 7), while 0.2 percent were laid off and 3.6 percent retired. In 2007, about 21.9 percent of all Canadian workers separated from their employers through quitting, layoffs or for other reasons (Morissette et al. 2013). About 6.4 percent of permanent workers were laid off, leaving 15.5 percent retiring, leaving their jobs voluntarily or being temporarily laid off. Assuming a total labour-force retirement rate equal to that of the federal public service, about 11.9 percent of all workers quit or temporarily separated - a much higher rate than the estimate for the federal public service. 
Finally, in managing total compensation costs, it should transition away from the pure defined-benefit pension model. Bill C-27 provides a framework for single-employer target-benefit pension plans, and for transition from defined-benefit to target-benefit plans - a package that should anticipate such changes in federal-employee plans. Target-benefit plans are an attractive option because they allow more benefit flexibility for the sake of more stability in contribution rates. A comparable alternative are shared-risk plans in which taxpayers do not bear all the risks related to the future cost of benefits, and in which a joint governance structure gives employee representatives a stake in the long-term sustainability of the plans. These are common elsewhere in Canada's public sector.

Employee compensation is not the federal government's biggest cost - it needs to manage the cost of its transfer payments and contain interest payments on its growing debt. But compensation is a major element of the federal budget, and has been growing at an unsustainable rate. Containing federal borrowing and avoiding future upward pressure to raise taxes will require Ottawa to curb the cost of its own employees. 


\section{References}

Canada. 2008. Study on Mobility of Public Servants. Ottawa: Public Service Commission of Canada.

- 2016a. Public Accounts of Canada 2015-2016, Volume 1, Summary Report and Financial Statements. Ottawa: Minister of Public Works and Government Services.

- 2016b. "Actuarial Report for the Pension Plan for the Public Service of Canada as at 31 March 2014.” Ottawa: Office of the Superintendent of Financial Institutions Canada.

—. 2016c. "Departmental Performance Reports." Various departments and agencies. Full listing available at https:/www.canada.ca/en/treasury-board-secretariat/services/departmental-performancereports/list-institutions-2015-2016-departmental-performance-reports.html. Accessed April 2017.

Hamilton, Malcolm. 2014. Evaluating Public-Sector Pensions: Are Federal Public Servants Overpaid? Commentary 405. Toronto: C.D. Howe Institute. April.

Lahey, James. 2011. “Controlling Federal Compensation Costs: Towards a Fairer and More Sustainable System.” In How Ottawa Spends, 2011-2012. Christopher Stoney and G. Bruce Doern (eds.). McGillQueen's University Press.

Morissette, René, Yuqian Lu, and Theresa Qiu. 2013. Worker Reallocation in Canada. Ottawa: Statistics Canada.

Office of the Parliamentary Budget Officer (OPBO). 2012. The Fiscal Impact of Federal Personnel Expenses: Trends and Developments. December.

Robson, William B.P., and Alexandre Laurin. 2016. Worse Than It Looks: The True Burden and Risks of Federal Employee Pension Plans. Commentary 449. Toronto: C.D. Howe Institute. May.

This E-Brief is a publication of the C.D. Howe Institute.

Alexandre Laurin is Director of Research at the C.D. Howe Institute.

William B.P. Robson is President and CEO at the C.D. Howe Institute.

This E-Brief is available at www.cdhowe.org.

Permission is granted to reprint this text if the content is not altered and proper attribution is provided. 